\title{
CECHY PROAKTYWNEJ OSOBOWOŚCI A ZACHOWANIA AUTOAGRESYWNE SKAZANYCH MĘŻCZYZN ODBYWAJĄCYCH KARĘ POZBAWIENIA WOLNOŚCI
}

BARTOSZ KWIATKOWSKI *

Areszt Śledczy w Opolu, Wyższa Szkoła Bankowa w Opolu, Polska

\section{STRESZCZENIE}

Obowiązek przymusowego przebywania w izolacji penitencjarnej wywołuje szkody osobiste $\mathrm{w}$ postaci zaburzeń emocji, motywacji czy zachowania. Negatywnym skutkiem deprywacji potrzeb skazanych jest ich podwyższona skłonność do dokonywania intencjonalnych samouszkodzeń podczas odbywania kary pozbawienia wolności. Oprócz czynników sprzyjających występowaniu zachowań autoagresywnych istnieją także czynniki chroniące, które bezspornie rzadziej są przedmiotem opracowań psychologicznych. W badaniu wzięło udział 50 skazanych mężczyzn, odbywających karę pozbawienia wolności po raz kolejny w życiu. Do ustalenia poziomu ich proaktywności wykorzystano Skale proaktywności w izolacji więziennej (SPIW15), natomiast ich skłonność do autoagresji ustalono przy użyciu Inwentarza samouszkodzeń (ISAS). W artykule omówiono wyniki badań własnych, które dowiodły, że proaktywność jako cecha osobowości ma negatywny związek $\mathrm{z}$ autoagresją recydywistów. W ochronie przed autoagresywnymi zachowaniami skazanych największy udział mają proaktywne działania nastawione na uzyskiwanie poczucia własnej kompetencji i wsparcia rodzinnego. Ponadto w badaniu wykazano, że proaktywni skazani PROAKTYWNOŚĆ AUTOAGRESJA RECYDYWIŚCI mają istotnie dłuższe przerwy między aktami autoagresji, a także ich proaktywne działania współwystępują z deklaracjami dotyczącymi chęci zaprzestania samouszkodzeń w przyszłości.

43 PROBLEM INTENCJONALNYCH SAMOUSZKODZEŃ W ŚRODOWISKU WIĘZIENNYM

44 CHARAKTERYSTYKA OSOBOWOŚCI PROAKTYWNEJ

46 METODA

48 WYNIKI

50 DYSKUSJA

54 BIBLIOGRAFIA 


\title{
THE CHARACTERISTICS OF PROACTIVE PERSONALITY AND AUTO-AGGRESSIVE BEHAVIOUR OF CONVICTED MEN SERVING A PRISON SENTENCE
}

\begin{abstract}
The obligation to be imprisoned in penitentiary isolation causes personal damages in the form of emotional, motivation or behavioral disorders. The negative effect of depriving needs of prisoners is their increased tendency to perform intentional self-harm while serving imprisonment. Besides to the factors contributing to the occurrence of self-aggressive behaviors, there are also protective factors that are undoubtedly less often subject to psychological studies.

The study involved 50 convicted men serving their sentences once again in their lives. To determine the level of their proactivity, The Scale of Proactivity in Penitentiary Isolation (PPI) was used, while their propensity to self-aggression was determined using The Inventory of Statements about self-injury (ISAS). The article discusses the results of our own research, which proved that proactivity as a personality trait has a negative relationship with self-aggression. Proactive actions aimed at gaining a sense of self-competence and family support are most important in the protection against the self-aggresion behaviour of convicts. Moreover, the study showed that proactive convicts have significantly longer intervals between acts of self-aggression, as well as their proactive activities coexist with declarations of the desire to stop self-harm in the future.
\end{abstract}

\section{KEYWORDS}

proactivity, self-aggression, recidivists 


\section{PROBLEM INTENCJONALNYCH SAMOUSZKODZEŃ W ŚRODOWISKU WIĘZIENNYM}

W powszechnej opinii zakłady karne są uważane za instytucje kryminogenne, powodujące wiele negatywnych konsekwencji. Odbywanie kary pozbawienia wolności utrudnia skazanym planowanie niekonwencjonalnych aktywności oraz podejmowanie niezależnych decyzji i działań przybliżających do realizacji celów osobistych. Z tych względów izolacja penitencjarna jest przykładem „niedemokratycznego” środowiska, w którym następuje wzrost impulsywności i agresywności (Shoham, Askenasy, Rahav, Chard, Addi, 1989). Niezwykle szkodliwym efektem uwięzienia jest także zamierzone i powtarzalne samouszkadzanie ciała, które w populacji osób pozbawionych wolności jest powiązane z wieloma heterogenicznymi przyczynami (Snow, 2002).

Analiza empiryczna przeprowadzona na amerykańskiej próbie skazanych dowodzi, że prawie 20\% kobiet i około 30\% mężczyzn dokonuje samouszkodzeń podczas przebywania w zakładach karnych (Appelbaum, Savageau, Trestman, Metzner, Baillargeon, 2011). Kolejnym wnioskiem $z$ cytowanego badania jest fakt, iż najwięcej samouszkodzeń odnotowano u skazanych odbywających karę pozbawienia wolności w jednostkach penitencjarnych, które miały maksymalny stopień zabezpieczeń i ochrony bezpieczeństwa. W brytyjskich zakładach karnych w samookaleczanie ciała częściej angażują się kobiety, jednak to wśród męskiej społeczności więziennej zaobserwowano 90\% wzrost tego rodzaju zachowań w latach 2006-2015 (Pope, 2018). Ponadto mężczyźni powodują u siebie poważniejsze obrażenia w obrębie całego organizmu, a także częściej dochodzi u nich do nagłej śmierci w wyniku samouszkodzenia. Coroczne dane statystyczne publikowane przez Centralny Zarząd Służby Więziennej zawierają jedynie informacje dotyczące autoagresji skutkującej rozstrojem zdrowia na okres powyżej siedmiu dni u osadzonych przebywających w polskich zakładach karnych. Brak danych poświęconych łagodnym i umiarkowanym aktom autoagresji utrudnia precyzyjne określenie problemu, który niewątpliwie jest jednym $\mathrm{z}$ bardziej newralgicznych i konstytutywnych z punktu widzenia współczesnego systemu penitencjarnego obowiązującego na terenie Rzeczpospolitej Polskiej.

Samouszkodzenia niezawierające intencji suicydalnych, a jedynie charakteryzujące się powtarzalnością występowania na różnych etapach odbywanej kary kryminalnej współwystępują z młodszym wiekiem badanych, cechami psychopatycznymi, a także popełnianiem wykroczeń dyscyplinarnych sprzecznych z zasadami obowiązującymi w izolacji (Lohner, Konrad, 2006). Wśród powszechnych form autoagresji wyróżnia się pocięcia powłok skórnych, podpalanie się, uderzanie głową w twardą powierzchnię, rozdrapywanie gojących się ran czy też połknięcia przedmiotów (Favazza, Rosenthal, 1993). W zakładach karnych dominującą formą są pocięcia, które skazani wykonują zazwyczaj na przedramionach, brzuchu, klatce piersiowej czy udach (Jones, 1986). Połknięcia ciał obcych zdarzają się rzadziej, ponieważ są trudniejsze do wykonania i wymagają przezwyciężenia odruchu wymiotnego oraz oporu psychicznego przed przyjęciem produktu niespożywczego (Linowski, Wysocki, 2006). Unikalną formą autodestrukcyjnych zachowań osadzonych są protesty głodowe, nastawione zasadniczo na wzbudzenie zainteresowania administracji zakładu karnego, prokuratury czy sądu. Odmowa przyjmowania posiłków rzadko jest odpowiedzią na doświadczane trudności emocjonalne, dlatego też niektórzy autorzy arbitralnie przyjmują, iż nie powinno się jej eksplikować jako konwencjonalnego aktu autoagresji (Wirkus, Kozłowski, 2008).

Główna przyczyna samouszkodzeń osób pozbawionych wolności wynika z potrzeby zredukowania negatywnych emocji (Dixon-Gordon, Harrison, Roesch, 2012). W nomenklaturze penitencjarnej pojawienie się aktu autoagresji jako odpowiedzi na pragnienie odczucia natychmiastowej ulgi od uciążliwego afektu jest równoznaczne $\mathrm{z}$ dokonaniem 
samouszkodzenia o charakterze emocjonalnym. Warto przytoczyć pogląd bazujący na wynikach wcześniejszych badań, iż wysoki poziom autoagresji fizycznej i emocjonalnej predysponuje do wybierania stylu radzenia sobie opartego na emocjach, nie zaś na konkretnym zadaniu (Chodak, Barwiński, 2010). Samouszkodzenie o charakterze emocjonalnym skutkuje sporządzeniem wniosku dyscyplinarnego, tymczasem dyrektor jednostki penitencjarnej zazwyczaj odstępuje od ukarania osadzonego, gdy merytoryczne konkluzje zawarte w opinii psychologicznej wskazują na niski poziom jego zasobów osobistych, tak potrzebnych do umiejętnego radzenia sobie $z$ nagromadzonym napięciem wewnętrznym. Konsekwencje dyscyplinarne ponoszą natomiast osadzeni samouszkadzający się z powodów instrumentalnych, kiedy głównym celem jest wzbudzenie zainteresowania personelu więziennego lub organów wymiaru sprawiedliwości (Snow, 2002). Autoagresja instrumentalna jest zatem specyficzną formą destrukcyjnego działania, spostrzeganego w kategoriach aktywności manipulacyjnych i stanowiących narzędzie szantażu. Na podstawie przeprowadzonego badania należy zaznaczyć, że personel więzienny ma poważną trudność w odróżnianiu samouszkodzeń „autentycznych” od „manipulacyjnych”, a także ma skłonność do przejawiania aktywnie wrogich postaw i zachowań wobec osadzonych dokonujących autoagresji zarówno z motywów emocjonalnych, jak i instrumentalnych (Marzano, Ciclitira, Adler, 2012).

W publikacjach naukowych precyzyjnie przedstawia się czynniki ryzyka zachowań autoagresywnych i ich funkcje (Fox i in., 2015; Lloyd-Richardson, Perrine, Dierker, Kelley, 2007). Wiele opracowań skupia się na wnikliwym dookreśleniu wrodzonych lub nabytych cech skazanych oraz na doświadczanych przez nich przeciwnościach życiowych, które decydują o predyspozycjach autoagresywnych (Kwiatkowski, 2018; Maden, Chamberlain, Gunn, 2000). Zdecydowanie rzadziej porusza się w literaturze temat czynników chroniących oraz występowania potencjalnych związków przyczynowo-skutkowych między nimi a czynnikami ryzyka. W kontekście środowiska więziennego należy stwierdzić, że nieczęsto prowadzi się badania podłużne ułatwiające rozpoznawanie przytoczonych czynników lub związków. Dodatkowo niewiele jest badań podkreślających wartość wybranych cech osobowości skazanych, które ułatwiają wdrażanie oddziaływań psychoterapeutycznych sprzyjających redukowaniu syndromu autoagresywnego (Snow, 2002). Przez niektórych autorów predyspozycje osobowościowe osób pozbawionych wolności są uważane za kluczowe wyznaczniki skutecznej adaptacji do warunków izolacyjnych (Sherman i in., 1997). Szczególne znaczenie przypisuje się wysokiej samoocenie, samokontroli, stabilności emocjonalnej, odporności na stres oraz podwyższonemu poziomowi uspołecznienia (Niewiadomska, 2007). Oprócz wymienionych cech docenia się zalety postawy proaktywnej, która akcentuje osiąganie celów przyszłościowych przez konstruktywne postępowanie w teraźniejszości (Kwiatkowski, 2016). Jak dotychczas w polskich jednostkach penitencjarnych nie prowadzono badań potwierdzających zależność proaktywności, stanowiącej integralną część osobowości osób karanych, z zachowaniami dezadaptacyjnymi, takimi jak czyny autoagresywne. Systematyczne eksplorowanie nowych obszarów badawczych może pozwolić na zidentyfikowanie kolejnych zasobów wewnętrznych osób przymusowo odseparowanych od społeczeństwa, a ich umiejętne rozpoznanie powinno przyczyniać się do wdrażania skuteczniejszych metod pracy resocjalizacyjnej, prowadzonej, aby zapobiegać aktom autoagresji, ale również aby chronić przez kontynuowaniem kariery przestępczej.

\section{CHARAKTERYSTYKA OSOBOWOŚCI PROAKTYWNEJ}

$\mathrm{Na}$ przestrzeni życia człowiek podejmuje rożnego rodzaju aktywności zmierzające do poprawy jego sytuacji w rzeczywistości społecznej. Wśród ludzi występują znaczne dysproporcje $\mathrm{w}$ podejmowaniu autonomicznych działań zwiększających w sposób pośredni prawdopodobieństwo dostosowania otaczającego środowiska do ich osobistych potrzeb. 
Możliwość restrukturyzacji warunków środowiskowych zależy od indywidualnej inicjatywy jednostki oraz silnego zaangażowania, a zatem dwóch kluczowych właściwości osobowości proaktywnej (Bateman, Crant, 1993).

W opracowaniach naukowych występuje wiele odmiennych perspektyw opisujących zagadnienie proaktywności. Niektórzy badacze rozpatrują je z punktu widzenia obserwowalnych zachowań człowieka przynoszących wymierne efekty w codziennym życiu (Parker, Williams, Turner, 2006), inni natomiast odnoszą proaktywność do działań nastawionych na osiąganie celów życiowych (Grant, Ashford, 2008). Fundamentalne stanowisko odwołuje się jednak do koncepcji proaktywnej osobowości, która zakłada występowanie indywidualnych różnic między ludźmi (Bateman, Crant, 1993). W tym ujęciu osoby obdarzone cechami osobowości proaktywnej próbują przejmować inicjatywę oraz podejmować relatywnie niezależne aktywności w celu zmiany samych siebie lub otaczającego środowiska. Ich dodatkowymi atrybutami są energiczność, wytrwałość, łatwość wypatrywania nadarzających się okazji do rozwoju personalnego oraz zdolność adaptacji do stale zmieniających się okoliczności i sytuacji nieprzewidywalnych (Parker i in., 2006).

W szerszym kontekście proaktywność jest utożsamiana z optymistyczną postawą oraz behawioralną strategią radzenia sobie w przezwyciężaniu barier zewnętrznych (Bańka, 2015). Restrykcje środowiska więziennego stanowią poważne utrudnienia dla osób pozbawionych wolności, które nie są również wolne od ograniczeń powstałych w procesie wadliwej socjalizacji. Dorastanie w rodzinach dysfunkcjonalnych sprzyja nadużywaniu alkoholu, narkotyków czy leków, co może w zauważalny sposób wpływać na poziom motywacji do kreatywnego projektowania realistycznych celów na każdym etapie życia. Proaktywność jako cecha osobowości składa się z pragmatycznych komponentów planowania, radzenia sobie i zarządzania własnymi aktywnościami (Aspinwall, 1997). Podwyższony poziom proaktywności pozwala minimalizować objawy lękowe pojawiające się przed rozpoczęciem nowych projektów czy twórczych przedsięwzięć. Sprawne funkcjonowanie w niesprzyjających warunkach wymaga wszczynania niewymuszonych aktywności, które przynoszą korzyści zarówno osobom sprawczym, jak i innym ludziom (Kwiatkowski, 2015). Generalnie postawa proaktywna jest nastawiona na korygowanie osobistego usytuowania życiowego, lecz jej korzystny wpływ zauważa się także w przypadku poprawy sytuacji własnych rodzin, osób bliskich czy postronnych. W pewnych okolicznościach proaktywność jednostki oddziałuje korzystnie na społeczeństwo, dlatego też w przestrzeni publicznej tego typu „osobliwe” przypadki zyskują aprobatę, uznanie czy szacunek (Bańka, 2009).

Przeciwieństwem proaktywnych działań jest postępowanie osób nieproaktywnych, u których prawdopodobieństwo zmiany aktualnej sytuacji lub samego siebie jest stosunkowo niewielkie. Charakterystyczna dla osób nieproaktywnych jest inklinacja do zachowań biernych oraz wybierania postaw zorientowanych wyłącznie na adaptację do teraźniejszych warunków (Crant, 1996). Oprócz tego indyferentność tych osób predysponuje je do regularnego projektowania jedynie prostych celów, osiąganych przy wykorzystaniu tradycyjnych trybów postępowania. Osoby nieproaktywne cechuje brak elastyczności oraz sceptyczny stosunek do dobrowolnych i narzuconych zadań. Ponadto ich motywacja jest niestabilna, gdyż pomimo zaplanowania aktywności czy nawet podjęcia już pewnych kroków zdarza im się rezygnować $z$ dalszego wykonywania rozpoczętych czynności. $Z$ tych powodów rzadziej występuje u nich gotowość do twórczego kreowania przedsięwzięć, które stanowi podstawę samorozwoju (Seibert, Crant, Kraimer, 1999).

Opracowania teoretyczne i empiryczne dowodzą, że cechy osobowości proaktywnej przyczyniają się do osiągania korzyści w obszarze masowego zatrudnienia, gdzie wyznacznikiem sukcesu zawodowego są osobiste dokonania (Strauss, Griffin, Rafferty, 2009). Dobroczynny wpływ proaktywności dostrzeżono u ludzi wykonujących prace standardowe (Grant, Rothbard, 2013), jak i zatrudnionych na stanowiskach wymagających podwyższonej odporności na stres (Sun, 2003). Negatywne zdarzenia, przyczyniające się do wzrostu 
napięcia emocjonalnego, a w konsekwencji do przewlekłego stresu, utrudniają realizowanie planów i celów życiowych. W grupie mężczyzn odbywających karę pozbawienia wolności dostrzeżono występowanie dodatniej zależności między pozytywnym afektem a proaktywnością, nie udowodniono natomiast związku między proaktywnością a odczuwanym przez nich afektem negatywnym (Kwiatkowski, 2015).

Badanie przeprowadzone w środowisku wolnościowym potwierdziło, że wysoko aktywowany pozytywny nastrój, obejmujący odczucie energii, inspiracji czy entuzjazmu, jest związany pozytywnie z elementami proaktywnego procesu działania (Bindl, Parker, Totterdell, Hagger-Johnson, 2012). W tym samym badaniu udowodniono, że wysoko aktywowany afekt pozytywny wspomaga poznawcze komponenty proaktywności i decyduje o podejmowaniu proaktywnych zachowań. Proaktywny proces działania składa się z przewidywania, planowania, rozważania i zarządzania, jednak wymienione elementy nie mają istotnego związku z pozytywnym nastrojem nisko aktywowanym (Bindl i in., 2012). Należy wszelako zaznaczyć, że nisko aktywowany nastrój negatywny jest predyktorem przewidywania proaktywnych celów oraz rozmyślania o przyszłych zmianach, natomiast nie decyduje o umiejętnościach kreatywnego działania w teraźniejszości.

\section{METODA}

\section{CEL BADANIA}

Każdego roku ponad 30 milionów ludzi „przechodzi” przez rozlokowane na obszarze całego świata instytucje penitencjarne (Fazel i in., 2016). Znaczny odsetek osób przymusowo izolowanych ma problem $\mathrm{z}$ rzeczowym i racjonalnym radzeniem sobie w zastanych realiach więziennych. Negatywnym wskaźnikiem zachowania dezadaptacyjnego jest skłonność do cielesnych samouszkodzeń, które pełnią wiele różnorodnych funkcji (Klonsky, Olino, 2008). Na podstawie wcześniejszych badań należy stwierdzić, że zachowań autoagresywnych nie sposób wyjaśnić tylko na podstawie stresu środowiskowego, a zatem warto uwzględniać także współistniejące zaburzenia osobowości, stwierdzane często u osób nieprzestrzegających porządku prawnego (Maden i in., 2000). Niewielka wiedza na temat czynników chroniących przed zjawiskiem autoagresji obecnym $\mathrm{w}$ środowisku więziennym sprawia, że istnieje realna potrzeba poszukiwania przytoczonych czynników w obszarach jak dotąd nieanalizowanych. Stąd też głównym celem prezentowanego badania było empiryczne sprawdzenie tezy, że proaktywność jako cecha osobowości może stanowić czynnik chroniący przed dokonywaniem samouszkodzeń podczas odbywania orzeczonej kary. Ostatecznie w badaniu postawiono cztery hipotezy badawcze:

H1: Podwyższony poziom proaktywności skazanych mężczyzn ma negatywny związek $z$ dokonywanymi przez nich intencjonalnymi samouszkodzeniami.

H2: Podwyższony poziom proaktywności skazanych mężczyzn ma pozytywny związek z czasem, jaki upłynął od chęci samouszkodzenia do momentu fizycznego dokonania autoagresji.

H3: Podwyższony poziom proaktywności skazanych mężczyzn ma pozytywny związek z ich deklaracjami dotyczącymi chęci zaprzestania dokonywania samouszkodzeń w przyszłości.

H4: Proaktywni skazani istotnie dłużej nie dokonują samouszkodzeń podczas odbywania kary pozbawienia wolności niż skazani nieproaktywni. 


\section{GRUPA BADANA}

Do uczestnictwa w badaniu zakwalifikowano 50 skazanych mężczyzn odbywających karę pozbawienia wolności w Areszcie Śledczym w Opolu. Opisywana jednostka penitencjarna jest miejscem, w którym na co dzień przebywają osoby aresztowane tymczasowo, ale także skazani odbywający orzeczoną karę po raz kolejny w swoim życiu. Jak pokazują wyniki dotychczasowych badań, wśród wielu czynników powodujących wzrost ryzyka dokonywania „ciężkich” okaleczeń znajduje się wcześniejsza karalność (Hawton, Linsell, Adeniji, Sariaslan, Fazel, 2014). W przedstawianym badaniu uczestniczyły zatem osoby karane wielokrotnie, które na podstawie dostępnej dokumentacji wychowawczej, psychologicznej lub psychiatrycznej charakteryzowały się osobistą historią autoagresji. Do procedury badania zostali włączeni zarówno skazani samouszkadzający się świadomie na wolności, jak też mający za sobą takie epizody podczas uprzedniego lub teraźniejszego pobytu w zakładzie karnym. Nie zastosowano innych kryteriów doboru próby oprócz sprawdzenia historii samouszkodzeń recydywistów. Skazani mężczyźni biorący udział w badaniu znajdowali się w przedziale wiekowym od 22 do 65 lat $(M=37,04 ; S D=10,98)$.

\section{NARZĘDZIA BADAWCZE}

W celu ustalenia poziomu proaktywności skazanych mężczyzn wykorzystano Skale proaktywności w izolacji więziennej (SPIW15) utworzoną przez Kwiatkowskiego i Bańkę (2013). Opisywana skala zawiera 15 pytań testowych, które są oceniane na 5-stopniowej skali, od „1” - „całkowicie się nie zgadzam” do „5” - „całkowicie się zgadzam”. Zaprezentowana metoda składa się z trzech niezależnych czynników, takich jak: proaktywność adaptacyjna doraźna (PAD), proaktywność adaptacyjna kontynuacyjna (PAK), proaktywność adaptacyjna projekcyjna (PAP). Przytoczone wymiary zawierają określoną pulę działań i aktywności możliwych do realizowania w rzeczywistości więziennej przez osoby pozbawione wolności. Proaktywność ogólna (PO) jest więc sumą wszystkich trzech czynników. Wartość współczynnika alfa Cronbacha dla całej skali wynosi 0,85 , dla poszczególnych jej wymiarów natomiast odpowiednio: proaktywność adaptacyjna doraźna - 0,84, proaktywność adaptacyjna kontynuacyjna - 0,85, proaktywność adaptacyjna projekcyjna - 0,84 (Kwiatkowski, 2015).

Historia autoagresji skazanych została sprawdzona za pomocą Inwentarza samouszkodzeń (Inventory of Statements about Self-injury - ISAS) skonstruowanego w 2008 roku. Twórcami przedstawianej metody są Klonsky i Olino (2008). W badaniu użyto pierwszej części narzędzia ISAS, w której należy wpisać przybliżoną liczbę celowo popełnionych samouszkodzeń. Do przykładowych zachowań tego typu zalicza się: pocięcia, podpalenia, rozdrapywanie gojących się ran, nakłuwanie się igłami, wyrywanie włosów czy też połknięcie niebezpiecznej substancji. Ponadto osoby badane muszą odpowiedzieć na kilka pytań, takich jak: W jakim wieku po raz pierwszy dokonałeś samouszkodzenia?; $\mathrm{W}$ jakim wieku po raz ostatni dokonałeś samouszkodzenia?; Czy w czasie dokonywania samouszkodzeń odczuwałeś cierpienie psychiczne?; Czy dokonujesz samouszkodzeń w samotności?; Zazwyczaj, ile czasu upłynęło od chęci dokonania samouszkodzenia do jego dokonania?; Czy chcesz zaprzestać dokonywania samouszkodzeń?. Rezygnacja z zastosowania drugiej części ISAS była podyktowana tym, iż w badanej grupie skazanych nie planowano sprawdzać poszczególnych funkcji aktów autoagresji zrealizowanych w przeszłości. Opisywana metoda charakteryzuje się dobrymi wynikami rzetelności $(\alpha=0,84)$, jak i trafności (Klonsky, Olino, 2008). 


\section{WYNIKI}

Analiza empiryczna sporządzona w oparciu o zebrany materiał badawczy pozwoliła na udzielenie odpowiedzi na postawione hipotezy badawcze. W pierwszej kolejności dokonano zestawienia statystyk opisowych dotyczących cech osobowości proaktywnej oraz samoagresji skazanych mężczyzn. W badanej grupie średni wynik proaktywności ogólnej wyniósł 48,84, odchylenie standardowe natomiast - 10,69. Poszczególne wymiary proaktywności charakteryzowały się następującymi rezultatami średnich i odchyleń standardowych: proaktywność adaptacyjna doraźna: $M=14,2 ; S D=5,47$, proaktywność adaptacyjna kontynuacyjna: $M=13,4 ; S D=4,02$, proaktywność adaptacyjna projekcyjna: $M=21,1$; $S D=5,45$

Średnia liczba dokonanych aktów autoagresywnych w analizowanej grupie to 15,52 , a odchylenie standardowe $-10,67$. Pierwsze samouszkodzenia skazanych były inicjowane w okresie adolescencji lub we wczesnej dorosłości $(M=16,4 ; S D=5,10)$. Ustalono również okres ostatniego samouszkodzenia, który znajdował się w przedziale od 1 do 24 miesięcy $(M=10,9 ; S D=8,79)$. U 40 mężczyzn podczas uszkadzania ciała występowało odczucie cierpienia psychicznego, u pozostałych natomiast występowało ono jedynie okazjonalnie $(N=5)$ lub nie było obecne w ogóle $(N=5)$. Ponadto stwierdzono, że 46 skazanych samouszkadzało się w samotności, tylko czterech zaś nie zważało na obecność innych osób w ich otoczeniu. Aż 41 skazanych zdecydowało się na akt autoagresji w czasie poniżej jednej godziny od wystąpienia takiego zamiaru. Pozostali uszkadzali się po upływie od jednej do trzech godzin $(N=6)$ lub zdecydowanie później $(N=3)$. Większość skazanych zadeklarowała, że nie chciałaby dokonywać samouszkodzeń w przyszłości $(N=41)$, choć byli i tacy, dla których samouszkodzenia pełnią ważną funkcję i nie zamierzają z nich rezygnować $(N=9)$.

Analiza korelacji liniowej $r$ Pearsona posłużyła do opracowania zebranych danych pochodzących od osób wielokrotnie karanych. W badaniu ustalono występowanie zależności między proaktywnością recydywistów a autoagresją i zmiennymi bezpośrednio z nią związanymi. $\mathrm{Na}$ podstawie osiągniętych wyników należy stwierdzić, że podwyższony poziom proaktywności skazanych ma negatywny związek z dokonywanymi przez nich samouszkodzeniami $(r=-0,57 ; p<0,01)$, a zatem pierwsza $z$ postawionych hipotez została potwierdzona. Poszczególne czynniki proaktywności skazanych także cechuje ujemna zależność od zachowań autoagresywnych. W toku przeprowadzonego badania nie udało się potwierdzić hipotezy drugiej, gdyż proaktywność ogólna nie ma istotnego związku z czasem, który upłynął od pojawienia się intencji autoagresyjnej aż do jej fizycznej realizacji $(r=0,19 ; p<$ 0,001). Z drugiej strony, uwidoczniła się pozytywna zależność jednego z czynników proaktywności, a konkretnie: proaktywności adaptacyjnej doraźnej z przytoczoną zmienną niezależną $(r=0,31 ; p<0,005)$. W tym kontekście należy zauważyć, że otrzymywane wsparcie od współosadzonych czy funkcjonariuszy może opóźniać dokonywanie samouszkodzeń u proaktywnych skazanych, a w wyjątkowych sytuacjach nawet im zapobiegać.

W badaniu udowodniono pozytywną zależność między proaktywnością ogólną, proaktywnością adaptacyjną doraźną i proaktywnością adaptacyjną projekcyjną a deklaracjami osadzonych dotyczącymi zaprzestania samouszkodzeń w przyszłości. Potwierdza to zatem pierwotne założenie trzeciej hipotezy, wskazując na umiarkowany związek między potrzebą zaniechania czynów autodestrukcyjnych a proaktywnością ogólną $(r=-0,456 ; p<0,001)$ i jej dwoma niezależnymi czynnikami. Szczegółowe wyniki współczynników korelacji proaktywności i jej czynników, jak również liczby aktów autoagresji skazanych mężczyzn oraz powiązanych $\mathrm{z}$ nimi zmiennych przedstawiono w tabeli 1 . 
Tabela 1. Wyniki korelacji Skali proaktywności w izolacji więziennej (SPIW15) i Inwentarza samouszkodzeń (ISAS) w grupie skazanych mężczyzn

\begin{tabular}{lccccccc}
\hline Zmienna & IS & PS & OS & CP & SS & CS & ZS \\
\hline P0 & $-0,573^{* *}$ & 0,062 & $0,446^{* *}$ & $-0,148$ & 0,038 & 0,186 & $0,456^{* *}$ \\
\hline PAD & $-0,354^{* *}$ & 0,003 & $0,489^{* *}$ & $-0,178$ & $-0,041$ & $0,307^{*}$ & $0,401^{* *}$ \\
\hline PAK & $-0,457^{* *}$ & 0,096 & 0,204 & 0,029 & 0,076 & 0,137 & 0,167 \\
\hline PAP & $-0,442^{* *}$ & 0,046 & 0,249 & $-0,143$ & 0,058 & $-0,038$ & $0,387^{* *}$ \\
\hline
\end{tabular}

Adnotacja. PO - proaktywność ogólna; PAD - proaktywność adaptacyjna doraźna; PAK - proaktywność adaptacyjna kontynuacyjna; PAP - proaktywność adaptacyjna projekcyjna; IS - intencjonalne samouszkodzenia; PS - pierwsze samouszkodzenie; OS - ostatnie samouszkodzenie; CP - odczuwane cierpienie psychiczne podczas dokonywania samouszkodzeń; SS - samouszkodzenie dokonywane w samotności; CS - czas od intencji autoagresywnej do momentu realnego samouszkodzenia; ZS - deklaracja zaprzestania dokonywania samouszkodzeń.

${ }^{*} p<0,05 ; * *^{* *} p<0,01$.

Zweryfikowanie ostatniej hipotezy wymagało zastosowania dwóch analiz statystycznych. Po pierwsze, interpretacji poddano wyniki korelacji $r$ Pearsona, a następnie przeprowadzono analizę istotności różnic międzygrupowych, wykorzystując do tego metodę $t$ Studenta dla prób niezależnych. Analiza współczynników korelacji dowiodła występowania istotnych zależności między ogólnym poziomem proaktywności $(r=0,446 ; p<0,001)$ i proaktywnością adaptacyjną doraźną $(r=0,489 ; p<0,001)$ a czasem, jaki upłynął od ostatniego samouszkodzenia. Interpretując osiągnięty rezultat, warto wskazać, że skazani inicjujący różnego rodzaju działania proaktywne rzadziej angażują się w zachowania autoagresywne. W ich przypadku szczególnie użyteczną aktywnością jest poszukiwanie informacji przydatnych $\mathrm{w}$ środowisku więziennym, co potwierdził istotny wynik korelacji między proaktywnością adaptacyjną doraźną a czasem od ostatniego samouszkodzenia.

Porównanie wyników dwóch grup skazanych miało na celu sprawdzenie, w której z nich wystąpiła dłuższa przerwa czasowa od ostatniego samookaleczenia. W pierwszej grupie znalazło się siedmiu mężczyzn, którzy osiągnęli niskie wyniki w skali SPIW15, osiem osób $\mathrm{z}$ wysokimi wynikami utworzyło natomiast grupę drugą. W przedstawianym opracowaniu nie przeanalizowano różnic między przytoczonymi grupami recydywistów a trzecią grupą skazanych, którą cechowały przeciętne wyniki w skali SPIW15. Warto zaznaczyć, że przeciętny poziom proaktywności stwierdzono aż u 35 recydywistów. Podsumowując, należy wskazać, że u osób z niskimi wynikami proaktywności średni czas od ostatniego samouszkodzenia był krótszy niż cztery miesiące $(M=3,71 ; S D=2,49)$, u osób o podwyższonych wynikach proaktywności wyniósł zaś niecałe 10 miesięcy $(M=9,87 ; S D=6,31)$. W tabeli 2 zaprezentowano wyniki średnich, odchyleń standardowych oraz błędu standardowego średniej czasu od dokonania ostatniego samouszkodzenia.

Tabela 2. Statystyki opisowe zmiennej niezależnej (OS) dla dwóch grup skazanych mężczyzn

\begin{tabular}{ccccc}
\hline OS & $\boldsymbol{N}$ & $\boldsymbol{M}$ & SD & $\begin{array}{c}\text { Błąd standardowy } \\
\text { średniej }\end{array}$ \\
\hline OSNP & 7 & 3,71 & 2,49 & 0,94 \\
\hline OSWP & 8 & 9,87 & 6,31 & 2,23 \\
\hline
\end{tabular}

Adnotacja. OS - czas od dokonania ostatniego samouszkodzenia; OSNP - czas od dokonania ostatniego samouszkodzenia w grupie skazanych z niskimi wynikami proaktywności; OSWP - czas od dokonania ostatniego samouszkodzenia w grupie skazanych z wysokimi wynikami proaktywności.

Przedstawiona w tabeli 3 analiza istotności, sprawdzona przy wykorzystaniu testu t Studenta dla prób niezależnych między wyszczególnionymi grupami skazanych świadczy, 
że średni czas, który upłynął od ostatniego samouszkodzenia, jest istotnie dłuższy u osób z podwyższonymi wynikami w skali SPIW15 w porównaniu do osób, które osiągnęły w niej niskie wyniki $(t(13)=-2,41 ; p=0,031)$. Na podstawie osiągniętych rezultatów należy skonstatować, iż proaktywni skazani przez inicjowanie działań zaradczych mogą skuteczniej radzić sobie z myślami autoagresywnymi, a zarazem odwlekać moment samouszkodzenia. Średnio sześć miesięcy różnicy między zachowaniami autoagresywnymi skazanych nieproaktywnych i proaktywnych jest wynikiem na tyle istotnym, aby stwierdzić, że proaktywność ułatwia przywidywanie skutków nieakceptowanych społecznie zachowań autodestrukcyjnych oraz podejmowanie konstruktywnych środków im zapobiegających.

Tabela 3. Wyniki istotności testu $t$ Studenta skazanych z niskimi $(N=7)$ oraz wysokimi $(N=8)$ wynikami proaktywności

\begin{tabular}{|c|c|c|c|c|c|c|c|c|}
\hline & \multicolumn{2}{|c|}{$\begin{array}{c}\text { Test Levene'a } \\
\text { jednorodności wariancji }\end{array}$} & \multicolumn{6}{|c|}{ Test $t$ równości średnich } \\
\hline & $F$ & Istotność & $t$ & $d f$ & Istotność & $d$ & $\begin{array}{l}\text { Różnica } \\
\text { średnich }\end{array}$ & $\begin{array}{l}\text { Błąd standardowy } \\
\text { różnicy }\end{array}$ \\
\hline $\mathrm{OS} \times \mathrm{PO}$ & 1,423 & 0,254 & $-2,413$ & 13 & 0,031 & $-1,34$ & $-6,160$ & 2,552 \\
\hline
\end{tabular}

Adnotacja. OS - czas od dokonania ostatniego samouszkodzenia; PO - proaktywność ogólna.

\section{DYSKUSJA}

Pod wieloma względami populacje zinstytucjonalizowane są bardziej narażone na podejmowanie zachowań autoagresywnych. W zakładach karnych, poprawczych czy psychiatrycznych częściej dochodzi do występowania aktów autoagresji, gdyż przebywające w nich osoby muszą zmagać się z licznymi trudnościami, a w szczególności z utratą poczucia kontroli i wolności (Jones, 1986). Instytucja więzienia jest więc źródłem negatywnych emocji, które mogą predysponować niektórych osadzonych do wybierania destabilizujących i dezintegrujących sposobów radzenia sobie w otaczającej rzeczywistości.

Istnieje wiele dowodów potwierdzających słuszność tezy, że samouszkodzenie jest dezadaptacyjną strategią działania, która w specyficznych okolicznościach staje się skutecznym sposobem rozwiązywania napotkanych przeciwności (Andover, Pepper, Gibb, 2007). Brak alternatywnych strategii radzenia sobie lub dysponowanie ograniczoną pulą zasobów zaradczych przekłada się na mniejsze możliwości działania w oparciu o orientację przyszłościową w sytuacjach trudnych lub ekstremalnych. Autoagresja jest specyficznym rodzajem dobrowolnego postępowania, które w zależności od rozmaitych zdarzeń życiowych może pełnić wiele odmiennych funkcji (Klonsky, Olino, 2008). Zasadniczo samouszkodzenie jest nastawione na regulację afektu, eliminując przy tym poczucie pustki, strachu czy złości (Herpertz, 1995). W innych przypadkach ma na celu wyznaczenie granic interpersonalnych, ochronę przed popełnieniem samobójstwa czy też wywarcie wpływu na osoby z własnego otoczenia. W społeczności więziennej manipulowanie innymi ludźmi oraz brak dostępu do efektywniejszych sposobów zwrócenia na siebie uwagi są uważane za istotne predyktory autoagresji (Fillmore, Dell, 2001).

W genezie powstawania zachowań autoagresywnych kluczowe znaczenie mają zróżnicowane czynniki intelektualne, osobowościowe oraz środowiskowe (Fox i in., 2015; Lloyd-Richardson i in., 2007). W dalszym ciągu więcej uwagi poświęca się korelatom zachowań autoagresywnych, czego dowodem są liczne publikacje naukowe poświęcone temu zagadnieniu, niezwykle rzadko natomiast sprawdza się i opisuje czynniki chroniące przed syndromem samouszkodzeniowym. Wykorzystywanie niewymuszonych aktywności ułatwia 
ludziom radzenie sobie ze stresem, co wpisuje się w ideę proaktywnej osobowości opartej na teorii interakcyjnej (Bateman, Crant, 1993). Z tego powodu przed rozpoczęciem badań postawiono hipotezę wskazującą na związek cech proaktywnej osobowości skazanych mężczyzn $z$ ich zachowaniami autoagresywnymi. W oparciu o uzyskane wyniki udowodniono, że podwyższony poziom proaktywności ma negatywny związek $\mathrm{z}$ dokonywanymi samouszkodzeniami. $Z$ tej perspektywy zabezpieczenie przed autoagresją następuje przez wykorzystywanie autonomicznych i zróżnicowanych aktywności, wśród których naczelne znaczenie mają działania ukierunkowane na uzyskiwanie poczucia własnej kompetencji i wsparcia rodzinnego. Przedstawiony wniosek jest oparty na tym, iż spośród wszystkich czynników proaktywności to proaktywność adaptacyjna kontynuacyjna okazała się najsilniej związana $z$ autoagresywnymi czynami recydywistów.

W poprawie relacji rodzinnych osób pozbawionych wolności ważną rolę odgrywają funkcjonariusze i pracownicy zatrudnieni w jednostkach penitencjarnych (McCarthy, Adams, 2019). Presja poszukiwania solidnego wsparcia wśród kadry penitencjarnej i współosadzonych jest większa u proaktywnych skazanych. Ten rodzaj suwerennego postępowania jest charakterystyczny dla osób obdarzonych podwyższonym poziomem proaktywności adaptacyjnej doraźnej, tymczasem proaktywność adaptacyjna projekcyjna w swojej istocie odnosi się do regularnego inicjowania aktywności, które sprzyjają uzyskiwaniu specjalistycznych informacji oraz nawiązywaniu kontaktów międzyludzkich. Sprawność i łatwość $\mathrm{w}$ pozyskiwaniu informacji dotyczących obowiązujących regulacji prawnych oraz innych istotnych spraw może się przyczyniać do odczuwania negatywnych emocji o mniejszym natężeniu. Podobną rolę może odgrywać nawiązywanie satysfakcjonującego kontaktu $\mathrm{z}$ adwokatami, kuratorami, pracownikami socjalnymi oraz instytucjami państwowymi i międzynarodowymi.

Z teoretycznego, jak i metodologicznego punktu widzenia odbywanie kary pozbawienia wolności wiąże się z licznymi niedogodnościami, które współwystępują z wrażeniem nieustannego niebezpieczeństwa i alienacji (Appelbaum i in., 2011; Ramluggun, 2013). Pomimo tego warto zaznaczyć, że utrzymywanie zadowalających relacji ze współosadzonymi czy funkcjonariuszami może chronić przed dokonywaniem samouszkodzeń w okresie przymusowej izolacji. Przytoczony wniosek stanowi częściowe potwierdzenie przyjętej początkowo hipotezy, ponieważ tylko proaktywność adaptacyjna doraźna ma pozytywny związek z czasem, który upłynął od wystąpienia intencji autoagresywnej do momentu realnego samouszkodzenia. Proaktywność ogólna, proaktywność adaptacyjna kontynuacyjna i projekcyjna nie korelują zatem $z$ wymienioną zmienną. Osiągnięty rezultat pozwala stwierdzić, że niezwłoczne staranie się proaktywnych skazanych o pomoc ze strony współosadzonych, wychowawców, psychologów, terapeutów, funkcjonariuszy działu ochrony lub służby zdrowia może odwlec zrealizowanie aktu autoagresji. W badanej grupie skazanych mężczyzn dowiedziono, że u większości z nich pojawienie się zamiaru autodestrukcyjnego powoduje jego „urealnienie” w czasie poniżej godziny. Priorytetem powinno być zatem dostarczanie skazanym wymaganego, a zarazem kompleksowego wsparcia w krótkim odstępie czasu. Znaczna część populacji więziennej ma poważny problem $\mathrm{z}$ odroczeniem autoagresji, co poniekąd należy interpretować występowaniem istotnej zależności między impulsywnością skazanych a ich patologicznymi samouszkodzeniami (Carli i in., 2010).

Całkowite wyzbycie się samouszkodzeń $z$ repertuaru zachowań dezadaptacyjnych jest jednym $z$ podstawowych celów skazanych. $W$ opinii personelu więziennego oraz osadzonych system penitencjarny zawiera poważne mankamenty, ograniczając przy tym wdrażanie „realnej” pomocy dla osób z tendencjami autoagresywnymi (Ramluggun, 2013). W badaniu udało się potwierdzić zakładaną hipotezę stanowiącą, że wysoki poziom proaktywności ma pozytywny związek z deklaracjami skazanych, które odnoszą się do osobistej potrzeby zaprzestania dokonywania następnych samouszkodzeń. W tym kontekście cechy proaktywnej osobowości pozwalające na zmianę otaczających warunków środowiskowych i wybranych 
deficytów personalnych mają również wpływ na postawy skazanych względem samouszkodzeń przez uwzględnianie i umyślne rozważanie autodestrukcyjnych doświadczeń innych osadzonych. Funkcję ochronną mogą także pełnić wiedza i zdolności uzyskane w trakcie zrealizowanych oddziaływań wychowawczych lub psychologicznych. Ponadto za adekwatne przykłady proaktywnych działań skazanych, które kształtują ich krytyczne nastawienie wobec dokonywania przyszłych samouszkodzeń, należy uznać poszukiwanie informacji przydatnych z perspektywy aktualnie odbywanej kary oraz budowanie sieci kontaktów społecznych.

Podwyższony poziom proaktywności osadzonych przyczynia się do podejmowania kreatywnych działań ukierunkowanych na poprawę przyszłej sytuacji życiowej (Kwiatkowski, 2016). Na podstawie przeprowadzonego badania należy także stwierdzić, że podwyższony poziom proaktywności recydywistów umożliwia sprawniejsze powstrzymywanie się od samouszkodzeń. U podłoża determinacji i oporu, czyli nieodzownych predyspozycji osobistych wymaganych do ograniczenia aktów autoagresji, leży umiejętność planowania przyszłych celów oraz ich realizowania za sprawą proaktywnych działań. Wyniki badań wskazały jednoznacznie, że poszukiwanie przychylnych wzmocnień i użytecznego wsparcia od współosadzonych czy personelu więziennego ma związek $z$ wydłużeniem czasu bez autoagresji. Porównanie skazanych proaktywnych z nieproaktywnymi potwierdziło zatem przyjętą hipotezę, że osoby z wysokim poziomem proaktywności istotnie rzadziej dokonują dobrowolnych samouszkodzeń w zakładzie karnym. Warto podkreślić, że mniejsza liczba aktów autoagresji osób pozbawionych wolności przekłada się na niższe nakłady finansowe wydatkowane przez system penitencjarny, który w razie potrzeby umożliwia opatrzenie samookaleczenia osadzonego lub wykonanie innych czynności lekarskich w zewnętrznej placówce medycznej (Kwiatkowski, 2018).

Proaktywność będąca cechą skazanych podejmujących ponadprzeciętny wysiłek ułatwia ingerowanie w bariery środowiskowe, a także może sprzyjać redukcji wyuczonych i niewłaściwych zachowań. Proaktywne działania mogą stanowić jedną z wielu technik zmniejszających odczuwane napięcie wewnętrzne, a jednocześnie pośrednio przyczyniających się do rzadszego uszkadzania ciała. Zaprezentowany wniosek należałoby jednak poddać weryfikacji empirycznej w badaniach wśród kobiet pozbawionych wolności lub innych osób objętych obowiązkową i uciążliwą izolacją. W tym aspekcie korzyścią byłoby poszerzenie obszaru badawczego o ludzi, którzy pozostają hospitalizowani w oddziałach psychiatrycznych, jak również o młodzież przebywającą w ośrodkach szkolno-wychowawczych lub zakładach poprawczych. Niewątpliwie skupienie się na pożytecznych cechach osobowości osób izolowanych od społeczeństwa może zahamować powstawanie dalszych zaburzeń w obrębie ich zachowania, w tym również prób samobójczych, które są pozytywnie skorelowane $\mathrm{z}$ tendencjami autoagresywnymi (Cooper i in., 2005).

We współczesnych systemach penitencjarnych rekomendowane interwencje psychologiczne mają na celu zapobieganie samobójstwom oraz autoagresji osób pozbawionych wolności (Barker, Kõlves, De Leo, 2014). Wykazanie, iż proaktywni skazani różnią się od nieproaktywnych skłonnością do autoagresji, stanowi sygnał, że warto szczególnie wnikliwie zastanowić się nad potencjalnymi oddziaływaniami resocjalizacyjnymi kierowanymi do wymienionych grup osadzonych. Proaktywni skazani powinni chętniej uczestniczyć w różnego rodzaju oddziaływaniach, które zapobiegają nawracaniu myśli autodestrukcyjnych w więziennej codzienności. Wobec nich nadzwyczaj użyteczne może się okazać zastosowanie pewnych elementów terapii dialektyczno-behawioralnej oraz prowadzenie zajęć edukacyjnych poświęconych anatomii i fizjologii człowieka lub technikom pierwszej pomocy (Pembroke, 2006). W kierunku skazanych nieproaktywnych warto natomiast prowadzić zabiegi psychokorekcyjne, które są możliwe do zrealizowania na kilku indywidualnych czy grupowych spotkaniach - zważywszy na ich niewielki poziom motywacji do pogłębionej pracy terapeutycznej. Dodatkowym efektem produktywnej współpracy personelu 
więziennego z osadzonymi charakteryzującymi się niskim poziomem proaktywności może być zauważalna zmiana ich zaangażowania, czyli jednego z najważniejszych aspektów proaktywności. Pomyślną konsekwencją proaktywności skazanych może być także większa podatność na proponowane oddziaływania resocjalizacyjne, które są konstytutywnie nastawione na redukcję poważnych deficytów wewnętrznych i zewnętrznych odpowiedzialnych za świadomy wybór przestępczego stylu życia. 


\section{BIBLIOGRAFIA}

Appelbaum, K. L., Savageau, J. A., Trestman, R. L., Metzner, J. L., Baillargeon, J. (2011). A national survey of self-injurious behavior in American prisons. Psychiatric Services, 62, 285-290. D0I: 10.1176/ps.62.3.pss6203_0285

Andover, M. S., Pepper, C. M., Gibb, B. E. (2007). Self-mutilation and coping strategies in a college sample. Suicide and Life-Threatening Behavior, 37, 238-243. D01: 10.1521/suli.2007.37.2.238

Aspinwall, L. G., Taylor, S. E. (1997). A stitch in time: self-regulation and proactive coping. Psychological Bulletin, 121, 417-436. D0l: 10.1037/0033-2909.121.3.417 Bańka, A. (2009). Proaktywność - intencjonalne konstruowanie przyszłości i uprzedzające osiąganie celów personalnych poprzez doświadczanie codzienności. W: H. Wrona-Polańska, W. Czerniawska, L. Wrona (red.), Szkice o ludzkim poznawaniu i odczuwaniu (s. 10-23). Kraków: Uniwersytet Pedagogiczny.

Bańka, A. (2015). Intencjonalne konstruowanie przyszłości i wyprzedzające realizowanie celów: walidacja Skali Proaktywności Ogólnej. Czasopismo Psychologiczne, 21,97-115. D0I: 10.14691/CPPJ.21.1.97

Barker, E., Kölves, K., De Leo, D. (2014). Management of suicidal and self-harming behaviors in prisons: systematic literature review of evidence-based activities. Archives of Suicide Research, 18, 227-240. D01: 10.1080/13811118.2013.824830

Bateman, T. S., Crant, J. M. (1993). The proactive component of organizational behavior. Journal of Organizational Behavior, 14, 103-118. D0I: 10.1002/ job.4030140202

Bindl, U. K., Parker, S. K., Totterdell, P., Hagger-Johnson, G. (2012). Fuel of the self-starter: How mood relates to proactive goal regulation. Journal of Applied Psychology, 97, 134-150. D0l: 10.1037/a0024368

Carli, V., Jovanović, N., Podlešek, A., Roy A., Rihmer, Z., Maggi, S., .. Sarchiapone, M. (2010). The role of impulsivity in self-mutilators, suicide ideators and suicide attempters - a study of 1265 male incarcerated individuals. Journal of Affective Disorders, 123(1-3), 116-122. D0l: 10.1016/j.jad.2010.02.119

Chodak, M., Barwiński, Ł. (2010). Autoagresja jako forma radzenia sobie ze stresem - przegląd zagadnień. Psychiatria i Psychoterapia, 6(1), 19-30. Pobrane z: http:// www.psychiatriapolska.pl/uploads/images/PiPWiosna2010t6n1/PiPt6n1s19s30MChodak1.pdf

Cooper, J., Kapur, N., Webb, R., Lawlor, M., Guthrie, E., Mackway-Jones, K., Appleby, L. (2005). Suicide after deliberate self-harm: a 4-year cohort study. American Journal of Psychiatry, 162, 297-303. D0I: 10.1176/appi.ajp.162.2.297

Crant, J. M. (1996). The Proactive Personality Scale as a predictor of entrepreneurial intentions. Journal of Small Business Management, 34, 42-49.

Dixon-Gordon, K., Harrison, N., Roesch, R. (2012). Non-suicidal self-injury within offender populations: a systematic review. International Journal of Forensic Mental Health, 11,33-50. DOl: 10.1080/14999013.2012.667513

Favazza, A. R., Rosenthal, R. J. (1993). Diagnostic issues in self-mutilation. Hospital and Community Psychiatry, 44, 134-140. D0I: 10.1176/ps.44.2.134

Fazel, S., Hayes, A. J., Bartellas, K., Clerici, M., Trestman, R. (2016). Mental health of prisoners: prevalence, adverse outcomes, and interventions. The Lancet Psychiatry, 3, 871-881. D0l: 10.1016/S2215-0366(16)30142-0

Fillmore, C., Dell, C. (2000). Prairie women, violence and self-harm. Winnipeg: Elizabeth Fry Society of Manitoba. Pobrane z: http://www.antoniocasella.eu/salute/ Fillmore_women_incarcerated_self-harm_2000.pdf

Fox, K. R., Franklin, J. C., Ribeiro, J. D., Kleiman, E. M., Bentley, K. H., Nock, M. K. (2015). Meta-analysis of risk factors for nonsuicidal self-injury. Clinical Psychology Review, 42, 156-167. D01: 10.1016/j.cpr.2015.09.002

Grant, A. M., Ashford, S.J. (2008). The dynamics of proactivity at work. Research in Organizational Behavior, 28, 3-34. D0I: 10.1016/j.riob.2008.04.002

Grant, A. M., Rothbard, N. P. (2013). When in doubt, seize the day? Security values, prosocial values, and proactivity under ambiguity. Journal of Applied Psychology, 98, 810-819. DOl: 10.1037/a0032873

Hawton, K., Linsell, L., Adeniji, T., Sariaslan, A., Fazel, S. (2014). Self-harm in prisons in England and Wales: an epidemiological study of prevalence, risk factors, clustering, and subsequent suicide. The Lancet, 383, 1147-1154. D0I: 10.1016/S0140-6736(13)62118-2

Herpertz, S. (1995). Self-injurious behaviour: psychopathological and nosological characteristics in subtypes of self-injurers. Acta Psychiatrica Scandinavica, 91 , 57-68. D0I: 10.1111/j.1600-0447.1995.tb09743.x

Jones, A. (1986). Self-mutilation in prison: a comparison of mutilators and nonmutilators. Criminal Justice and Behavior, 13, 286-296. D0l: $10.1177 / 0093854886013003003$

Klonsky, E. D., Olino, T. M. (2008). Identifying clinically distinct subgroups of self-injurers among young adults: a latent class analysis. Journal of Consulting and Clinical Psychology, 76, 22-27. D0I: 10.1037/0022-006X.76.1.22

Kwiatkowski, B., Bańka, A. (2013). Wstępna charakterystyka psychometryczna Skali Proaktywności w Izolacji Więziennej (SPIW). Czasopismo Psychologiczne, 19 , 361-373. D0l: 10.14691/CPPJ.19.2.361

Kwiatkowski, B. (2015). Dalsza walidacja Skali Proaktywności w Izolacji Więziennej. Czasopismo Psychologiczne, 21, 239-251. D01: 10.14691/CPPJ.21.2.239

Kwiatkowski, B. (2016). Proaktywne konstruowanie przyszłości w izolacji więziennej. Przegląd Więziennictwa Polskiego, 93, 43-59. Pobrane z: https://sw.gov.pl/ assets/26/79/75/479dbc0e656f47a448edc32f7255aceea5bfe471.pdf

Kwiatkowski, B. (2018). Predyktory zachowań autoagresywnych kobiet odbywających karę pozbawienia wolności. Przegląd Więziennictwa Polskiego, 99, $101-117$. Pobrane z: http://pwp.edu.pl/view/abstracts/issue_id/441

Linowski, K., Wysocki, I. (2006). Oddziaływania psychokorekcyjne na skazanych agresywnych w warunkach penitencjarnych. Ostrowiec Świętokrzyski: Stowarzyszenie na Rzecz Rozwoju Wyższej Szkoły Biznesu i Przedsiębiorczości.

Lohner, J., Konrad, N. (2006). Deliberate self-harm and suicide attempt in custody: distinguishing features in male inmates self-injurious behavior. International Journal of Law and Psychiatry, 29, 370-385. D01: 10.1016/j.jijp.2006.03.004

Lloyd-Richardson, E. E., Perrine, N., Dierker, L., Kelley, M. L. (2007). Characteristics and functions of non-suicidal self-injury in a community sample of adolescents. Psychological Medicine, 37, 1183-1192. D0I: 10.1017/S003329170700027X

Maden, A., Chamberlain, S., Gunn, J. (2000). Deliberate self-harm in sentenced male prisoners in England and Wales: some ethnic factors. Criminal Behaviour and Mental Health, 10, 199-204. D0l: 10.1002/cbm.357 
McCarthy, D., Adams, M. (2019). Can family - prisoner relationships ever improve during incarceration? Examining the primary caregivers of incarcerated young men. British Journal of Criminology, 59, 378-395. D0l: 10.1093/bjc/azy039

Marzano, L., Ciclitira, K., Adler, J. (2012). The impact of prison staff responses on self-harming behaviours: prisoners perspectives. British Journal of Clinical Psychology, 51, 4-18. DOI: 10.1111/j.2044-8260.2010.02007.x

Niewiadomska, I. (2007). Osobowościowe uwarunkowania skuteczności kary pozbawienia wolności. Lublin: Wydawnictwo KUL.

Parker, S. K., Williams, H. M., Turner, N. (2006). Modeling the antecedents of proactive behavior at work. Journal of Applied Psychology, 91, 636-652. D0I: 10.1037/0021-9010.91.3.636

Pembroke, L. (2006). Limiting self harm. Emergency Nurse, 14(5), 8-10. D0I: 10.7748/en.14.5.8.s13

Pope, L. (2018). Self-harm by adult men in prison: a rapid evidence assessment (REA). London: Ministry of Justice. Pobrane z: https://www.gov.uk/government/ publications/self-harm-by-adult-men-in-prison-a-rapid-evidence-assessment

Ramluggun, P. (2013). A critical exploration of the management of self-harm in a male custodial setting: qualitative findings of a comparative analysis of prison staff views on self-harm. Journal of Forensic Nursing, 9, 23-34. D0l: 10.1097/JFN.0b013e31827a5984

Seibert, S. E., Crant, J. M., Kraimer, M. L. (1999). Proactive personality and career success.Journal of Applied Psychology, 84, 416-427. D0I: 10.1037/0021-9010.84.3.416

Shoham, S. G., Askenasy, J. J., Rahav, G., Chard, F., Addi, A. (1989). Personality correlates of violent prisoners. Personality and Individual Differences, 10, 137-145. DOI: 10.1016/0191-8869(89)90197-9

Sherman, L. W., Gottfredson, D., MacKenzie, D., Eck, J., Reuter, P., Bushway, S., Department of Criminology and Criminal Justice University of Maryland (1997). Preventing crime: what works, what doesn't, what's promising: a report to the United States Congress. Washington, DC: US Department of Justice, National Institute of Justice (NCJ 165366). Pobrane z: https://www.ncjrs.gov/pdffiles1/Digitization/165366NCJRS.pdf

Snow, L. (2002). Prisoners' motives for self-injury and attempted suicide. The British Journal of Forensic Practice, 4(4), 18-29. D0I: 10.1108/14636646200200023

Strauss, K., Griffin, M., Rafferty, A. E. (2009). Proactivity directed toward the team and organization: The role of leadership, commitment and role-breadth self-efficacy. British Journal of Management, 20, 279-291. D0l: 10.1111/j.1467-8551.2008.00590.x

Sun, I. Y. (2003). Officer proactivity: a comparison between police field training officers and non-field training officers. Journal of Criminal Justice, 31, 265-277. D0I: $10.1016 / 50047-2352(03) 00007-2$

Wirkus, Ł., Kozłowski, P. (2008). Izolacja więzienna a zachowania autoagresywne więźniów. W: A. Jaworska (red.), Kryminologia i kara kryminalna. Wybrane zagadnienia (s. 191-218). Kraków: Oficyna Wydawnicza „Impuls". 